

\section{Kelompok 4}

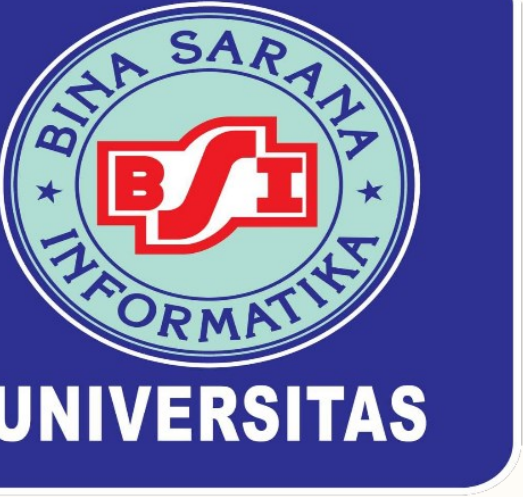

DJOSHI WILLIAM CHRISTOPER 73190077

FERY MAULANA IBRAHIM 73190053 


\section{Ukuran Gejala Pusat Data belum dikelompokkan}
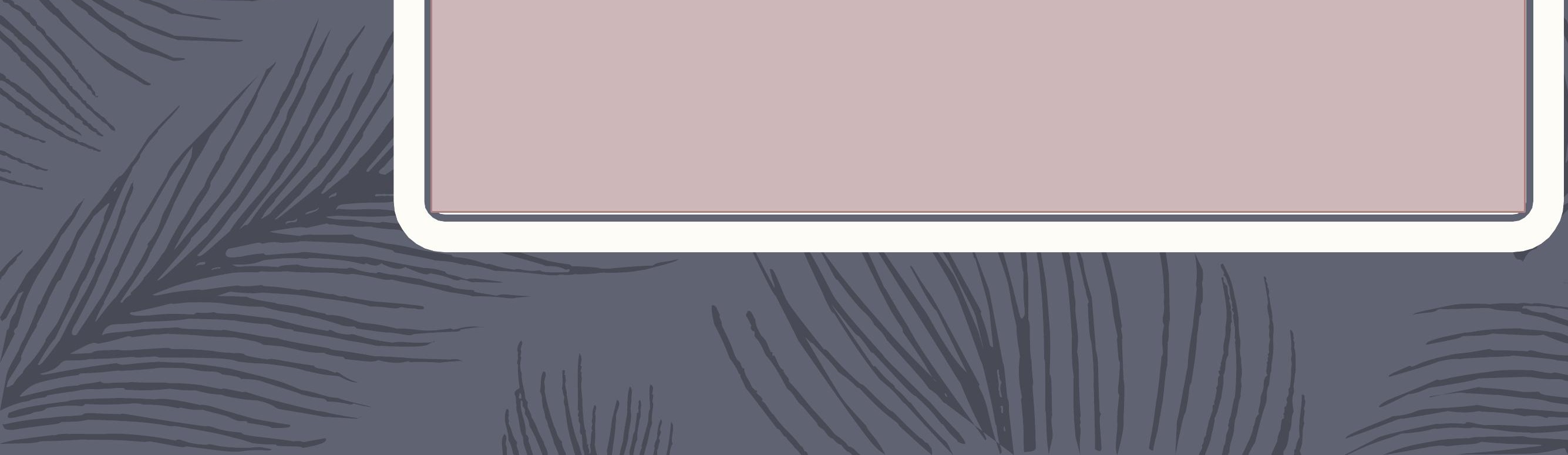


\section{Pengertian}

Ukuran gejala pusat data belum dikelompokkan adalah data yang tidak disusun ke dalam distribusi frekuensi sehingga tidak mempunyai interval kelas dan titik tengah kelas. Setiap penimbang/bobot tersebut merupakan pasangan setiap data. 


\section{Macam-Macam Ukuran Gejala Pusat Data Belum Dikelompokkan}

- 1. Rata-rata Hitung

2. Rata-rata Ukur

3. Rata-rata Harmonis

- 4. Median

- 5. Modus

- 6. Kuartil

- 7. Desil

- 8. Persentil 


\section{Rata-Rata Hitung (Mean)}

Rata-rata hitung dapat kita sebut juga dengan mean yaitu jumlah nilai suatu data dibagi dengan banyaknya data akan menghasilkan rata-rata nilai suatu data tersebut. Rata-rata hitung dinyatakan dengan notasi $X$ untuk sampel.

Rumus :

$$
X=\frac{1}{N} \sum x_{i}
$$

Keterangan : $\sum x=$ Jumlah Data

$$
\begin{aligned}
& \mathbf{N}=\text { Banyaknya Data } \\
& x_{\boldsymbol{i}}=\text { Data ke }-\boldsymbol{i}
\end{aligned}
$$




\section{Contoh Rata-Rata Hitung (Mean)}

Hitunglah rata-rata dari data $6,6,4,6,2,5,5,6,7,6,8,6,6,4,6,2,5,5,6,7,6,8$ ! Jawab:

Dari data tersebut dapat kita ketahui bahwa jumlah data adalah $11(n=11)(n=11)$. Dengan menggunakan rumus kita dapat menghitung rata-ratanya.

$$
\begin{aligned}
x & =\frac{1}{n} \sum x_{i} \\
& =\frac{1}{11}(6+6+4+6+2+5+5+6+7+6+8) \\
& =\frac{1}{11}(61) \\
& =5,55
\end{aligned}
$$




\section{Rata-Rata Ukur (Geometri)}

Rata rata ukur/geometri dari sejumlah $\mathbf{N}$ nilai data adalah akar pangkat $\mathbf{N}$ dari hasil kali masing masing nilai dari kelompok tersebut.

$$
\begin{aligned}
& \text { Rumus: } \quad G=\sqrt[N]{x_{1} x_{2} x_{3} \ldots x_{n}} \\
& \text { atau } \\
& \log G=\frac{\sum \log x_{i}}{N} \\
& \text { Keterangan : } G=\text { adalah rata-rata ukur ( geometrik) } \\
& \boldsymbol{n}=\text { adalah banyaknya sampel } \\
& \sum=\text { adalah penjumlahan } \\
& \boldsymbol{x}_{\boldsymbol{i}}=\text { nilai data ke- } \boldsymbol{i}
\end{aligned}
$$




\section{Contoh Rata-Rata Ukur (Geometri)}

Diketahui data suku bunga tabungan beberapa bank adalah sebagai berikut.

6,$75 ; 5,75 ; 6,50 ; 6,25 ; 6,25 ; 6,10 ; 5,70 ; 5,90 ; 6,25 ; 5,60$

Berapakah rata-rata ukur (geometrik) suku bunga bank-bank tersebut?

Jawab:

Rata-rata ukur (geometrik) bisa dihitung dengan menggunakan rumus cara pertama atau rumus cara kedua. Cara penghitungannya adalah sebagai berikut.

$G=\sqrt[N]{x_{1} x_{2} x_{3} \ldots x_{n}}$

$=\sqrt[10]{6,75 \times 5,75 \times 6,50 \times 6,25 \times 6,25 \times 6,10 \times 5,70 \times 5,90 \times 6,25 \times 5,60}$

$=\sqrt[10]{70757056,11}$

$=6.095$ 


\section{Rata-Rata Harmonis}

Rata rata harmonis adalah kebalikan rata rata hitung dari kebalikan nilai nilai data.

Rumus: $\quad H=\frac{N}{\sum\left(\frac{1}{x_{i}}\right)}$

Keterangan : $\boldsymbol{H}=$ rata-rata harmonik

$\boldsymbol{n}=$ banyaknya data

$x_{i}=$ nilai data ke- $i$ 


\section{Contoh Rata-Rata Harmonis}

Rata-rata harmonis dari data $3,2,4,3$ adalah ...

Jawab:

$H=\frac{N}{\sum\left(\frac{1}{x_{i}}\right)}$

Data pada soal terdiri dari 4 angka sehingga $n=4$

Rata-rata dari 3, 2, 4, 3 adalah

$$
\begin{array}{ll}
=\frac{4}{\frac{1}{3}+\frac{1}{2}+\frac{1}{4}+\frac{1}{3}} & =4: \frac{17}{12} \\
=\frac{4}{\frac{4+6+3+4}{12}} & =4 \times \frac{12}{17} \\
=\frac{4}{\frac{17}{12}} & =2 \frac{48}{17} \\
& =2,823
\end{array}
$$




\section{Median}

Median adalah suatu ukuran pemusatan yang menempati posisi tengah jika data diurutkan menurut besarnya.

\section{Rumus :}

Jika N ganjil :

$$
\text { Med }=x\left(\frac{n+1}{2}\right)
$$

Jika $\mathbf{N}$ genap :

$$
\text { Med }=\frac{1}{2}\left(x_{\left(\frac{n}{2}\right)}+x_{\left(\frac{n}{2}\right)+1}\right)
$$

Keterangan $:$ Med $=$ median

$$
\begin{aligned}
& \mathbf{N}=\text { banyak data sampel } \\
& \mathrm{X}=\text { Nilai rata-rata }
\end{aligned}
$$




\section{Contoh Median}

\section{Rumus Median Jumlah Ganjil}

Med $=x\left(\frac{n+1}{2}\right)$

Contoh soal:

Lima orang anak menghitung jumlah kelereng yang dimilikinya, dari hasil penghitungan mereka diketahui jumlah kelereng mereka adalah sebagai berikut.

$5,6,7,3,2$

Median dari jumlah kelereng tersebut adalah?

Jawab:

Karena jumlah data adalah ganjil, maka penghitungan median menggunakan rumus median untuk data ganjil. Proses penghitungannya adalah sebagai berikut.

Med $=x\left(\frac{5+1}{2}\right)=x\left(\frac{6}{2}\right)=x_{3}$

Dari rumus matematis di atas, diperoleh bahwa median adalah $x 3$. Untuk mengetahui $x 3$, maka data harus diurutkan terlebih dahulu. Hasil pengurutan data adalah sebagai berikut.

$2,3,5,6,7$

Dari hasil pengurutan dapat kita ketahui mediannya $(x 3)$ adalah 5. 
Rumus Median Jumlah Genap

Med $=\frac{1}{2}\left(x_{\left(\frac{n}{2}\right)}+x_{\left(\frac{n}{2}+1\right)}\right)$

Contoh soal:

Sepuluh orang siswa dijadikan sampel dan dihitung tinggi badannya. Hasil pengukuran tinggi badan kesepuluh siswa tersebut adalah sebagai berikut.

$172,167,180,171,169,160,175,173,170,165$

Hitunglah median dari data tinggi badan siswa!

Jawaban:

Karena jumlah data genap, maka penghitungan median menggunakan rumus median untuk data genap. Proses penghitungannya adalah sebagai berikut.

Med $=\frac{1}{2}\left(x_{\left(\frac{10}{2}\right)}+x_{\left(\frac{10}{2}+1\right)}\right)=\frac{1}{2}\left(x_{5}+x_{6}\right)$

Untuk melanjutkan penghitungan, kita harus terlebih dahulu mengetahui nilai $x 5$ dan $x 6$. Kedua nilai data tersebut dapat diperoleh dengan mengurutkan semua data. Hasil pengurutan adalah sebagai berikut.

$160,165,167,169,170, \underline{171}, 172,173,175,180$

Dari pengurutan tersebut diperoleh nilai $x 5$ sama dengan 170 dan x6 sama dengan 171 . Dengan demikian penghitungan median dapat dilanjutkan.

Med $=\frac{1}{2}(170+171)=\frac{1}{2}(341)=170,5$ 


\section{Modus}

Modus adalah kumpulan data atau nilai yang sering muncul atau data yang mempunyai frekunsi terbesar, jika pada kumpulan data itu terdapat lebih dari satu data yang sama sama paling sering muncul, maka dalam kumpulan data itu terdapat lebih dari satu modus.

Rumus : Nilai yang paling sering muncul

Contoh :

Dik : 456788910

MODUS $=8$ 


\section{Kuartil}

Kuartil pada prinsipnya, pengertian kuartil sama dengan median. perbedaannya hanya terlekak pada banyaknya pembagian kelompok data. median membagi kelompok data atas 2 bagian, sedangkan kuartil membagi kelompok data atas 4 bagian yang sama besar, sehingga akan terdapat 3 kuartil yaitu kuartil ke-1, kuartil ke2 dan kuartil ke-3, dimana kuartil ke-2 sama dengan median.

$$
Q_{i=\frac{i(n+1)}{4}}
$$

$$
i=1,2,3
$$




\section{$\underline{\text { Contoh Kuartil }}$}

Diketahui :

$2,3,4,5,6,7,8,9,10,11$

Ditanya :

Cari Q1, Q2, Q3

$$
\begin{aligned}
\text { Q1 } & =1(n+1) / 4 \\
& =1(10+1) / 4 \\
& =11 / 4=2,75 \\
& =2+0,75 \\
& =X i+0,75(X i+1-x i) \\
& =X 2+0,75(X 2+1-X 2) \\
& =3+0,75(3+1-3) \\
& =3+0,75(4-3) \\
& =3+0,75=3,75
\end{aligned}
$$




$$
\begin{aligned}
\text { Q2 } & =2(n+1) / 4 \\
& =2(10+1) / 4 \\
& =22 / 4 \\
& =5,5 \\
& =5+0,5 \\
& =X i+0,5(X i+1-X i) \\
& =X 5+0,5(X 5+1-X 5) \\
& =6+0,5(6+1-6) \\
& =6+0,5(7-6)=6,5 \\
& =3(n+1) / 4 \\
& =3(10+1) / 4 \\
& =33 / 4 \\
& =8,25 \\
& =8+0,25 \\
& =X i+0,25(X i+1-X i) \\
& =X 8+0,25(X 8+1-X 8) \\
& =9+0,25(9+1-9) \\
& =9+0,25(10-9)=9,025
\end{aligned}
$$




\section{Desil}

Desil adalah suatu rangkaian data yang membagi distribusi menjadi 10 bagian yang sama besar.

$$
\begin{gathered}
D_{i=\frac{i(n+1)}{10}} \\
i=1,2,3, \ldots ., 9
\end{gathered}
$$




\section{Contoh Desil}

Data : $2,3,4,5,6,7,8,9,10,11$,

$\mathrm{n}=10$

Dit : D2

Jawab : $i(n+1) / 10$

$D 2=2(10+1) / 10$

$D 2=22 / 10$

$D 2=2,2$

$=2+0,2$

$D 2=X i+0,2(X i+1-X i)$

$D 2=X 2+0,2(X 2+1-X 2)$

$\mathrm{D} 2=3+0,2(4-3)$

$\mathrm{D} 2=3,2$ 


\section{Persentil}

Persentil adalah ukur letak yang membagi suatu distribusi menjadi 100 bagian yang sama besar.

$$
\begin{aligned}
& P_{i=\frac{i(n+1)}{100}} \\
& i=1,2,3, \ldots . ., 99
\end{aligned}
$$




\section{Contoh Persentil}

Data : 1112131415161718192021222324252627282930

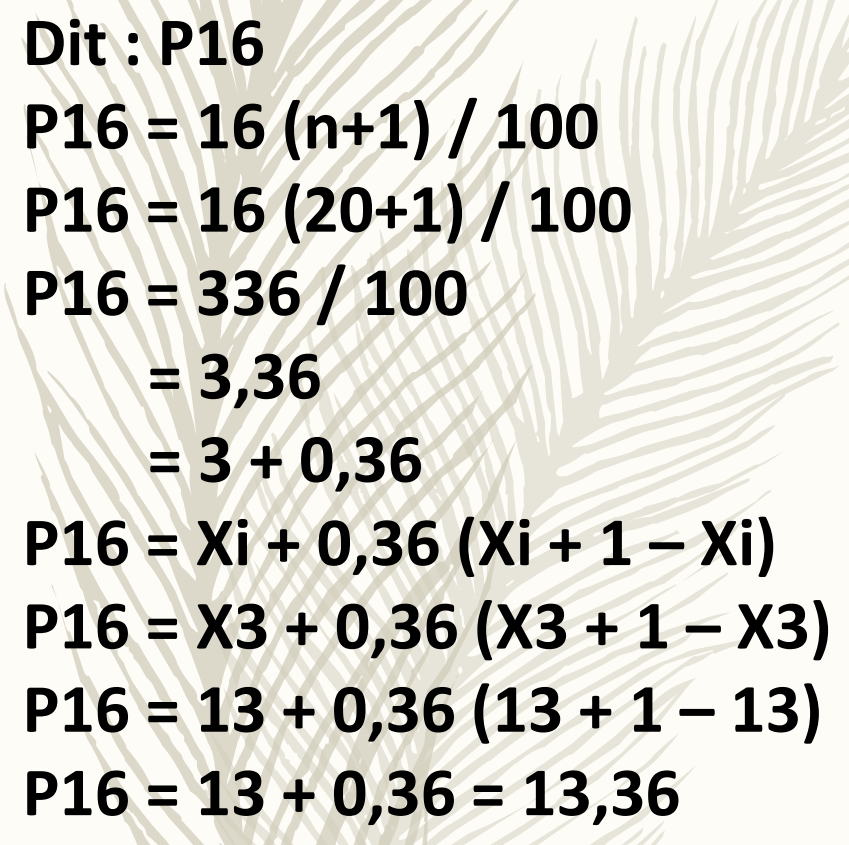




\section{Thank You}

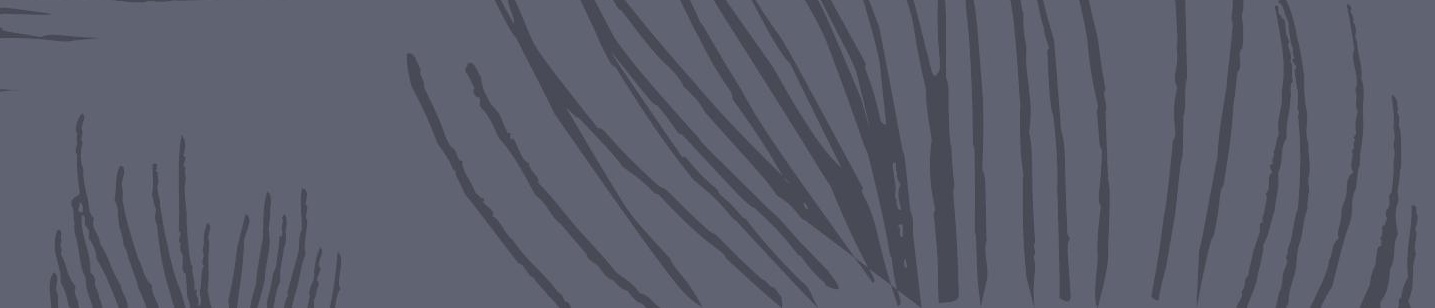

